\title{
Professional training of agricultural industry assistants as pedagogical problem
}

\author{
Nataliia Oliinyk ${ }^{1}$, Liubov Spiridonova Zolotarova ${ }^{2}$ \\ ${ }^{1}$ Candidate of pedagogical sciences, associate professor, Head of the department of physical education and psychological and \\ pedagogical disciplines. Vinnytsia National Agrarian University Management \\ ${ }^{2}$ Senior lecturer, Vice-rector for educational work and humanitarian policy, Vinnytsia National Agrarian University \\ Emails: natalia.oliinuk0480@gmail.com¹, zelinska.vnau@gmail.com²
}

\begin{abstract}
Improving the effectiveness of professional training of agricultural professionals is one of the priorities of the higher agricultural education system. The purpose of the article is to determine the main approaches to the professional training of agricultural specialists. According to the analysis of psychological and pedagogical literature, scientific contributions, the author gives the author's definition: "the willingness of future specialists in the agricultural sector to professional activity as an awareness of the need for purposeful obtaining theoretical knowledge, practical skills for self-formation, awareness of personal and social sphere. "We have identified three stages of professional preparation of students of agricultural profile in the conditions of higher education, the qualities that should be formed for each student: the desire for in-depth study of their profession, the development of interest in it; regular independent performance of educational tasks; honest execution of public tasks, active participation in public life; search for original, non-standard solutions to technical problems. The article emphasizes that the future specialist of agrarian industry requires a combination of deep production and technical knowledge on the one hand, and thorough knowledge of sociological issues - psychological knowledge that would allow effective management of production units and successfully work in different sectors of Ukraine. It is stated that in order to increase the effectiveness of students' education it is necessary to: know the goals of learning, that is, the final knowledge, skills and skills that they must acquire in the course of studying the disciplines; to find forms and methods of control that will allow to evaluate the degree of achievement of the goal, to understand what criteria should be followed in the organization of educational and cognitive activity; to develop programs for the organization of active conscious cognitive activity of each student for mastering the planned knowledge, skills and skills; to create in students appropriate motivation, interest and confidence in the importance and necessity of acquiring certain knowledge, skills and skills that would encourage each student to active conscious work.
\end{abstract}

Keywords: vocational training; specialists; agrarian sector; student; educational process.

\section{Introduction}

The development of the Ukrainian state, the current challenges, the European integration processes and the globalization of the labor market cause changes in the higher agricultural education system, in particular agrarian. In the conditions of market transformation of the agro-industrial complex, there is an urgent need to solve the problem of training agricultural specialists, who are able to use the existing social, natural, technological potential of today to bring Ukraine to the level of the leading countries of the world. After all, any domestic agro-industrial production requires highly skilled agrarian specialists, who are able to apply modern technologies in the production of agricultural products and in its processing and sale.

The implementation of the leading objectives of the National Strategy for the Development of Agrarian Education in Ukraine until 2021 requires further improvement of the activities of higher education institutions, in particular:

* bringing the network of agricultural higher education institutions and higher education management system in line with the needs of national economy development and labor market demands;

* creation of research universities, expansion of autonomy of higher education institutions;

* involvement of employers in cooperation with agrarian higher education institutions, in particular, participation in the development of higher education standards, organization of students' internships, solving the issue of the first job for graduates;

* further improvement of procedures and technologies of external independent evaluation of educational achievements of graduates of general secondary education who have expressed a desire to enter higher education institutions, as a prerequisite for ensuring equal access to higher education; 
re-equipment of educational, scientific-methodical and material-technical base of higher educational establishments [2, p.9].

Today, the training of agricultural specialists is focused on the training of industrial-type production personnel in the conditions of competition for world trade and marketing markets and needs improvement.

In this regard, it is important to study the trends of professional training of agricultural professionals in Ukraine in order to find ways and ways to improve them.

\section{Analysis of recent research and publications}

V. Abakumova, V. Beder, R. Gorbatiuk, O. Dubasevich, A. Kuzmin, E. Luzin, S. Sysoev, etc. made a significant contribution to the study of theoretical and methodological aspects of training of future specialists; the philosophical principles of the formation of the modern scientific-agrarian picture of the world and the philosophy of education - V. Andrushchenko, V. Kremen, O. Dzhezhula, V. Ognevyuk, O. Savchenko, E. Toffler and others; organization of professional training of future specialists in higher education (A. Alexiuk, S. Arkhangelsky, V. Bondar, M. Yevtukh, O. Meshchaninov, O. Padalka, V. Sagarda, O. Shestopaluk); management of systems of training of skilled workers (I. Likarchuk), development of personality of future specialists in the process of vocational training (V. Rybalko, V. Semichenko).

Analysis of the history of agrarian education was carried out by S. Bilan and S. Padalka. The problem of professional training of agricultural specialists was devoted to the research of the following national scientists: L. Avramchuk, A. Bugerko, A. Demin, D. Melnychuk. Besides, the problem of professional training of future agricultural specialists in the conditions of integration of education remained without the attention of the researchers. Therefore, we consider it appropriate to consider this problem in the context of analyzing the current situation in society by identifying the goals, objectives, features of the content and process of implementation of agricultural education and, accordingly, the requirements for vocational training.

The purpose of the article is to identify the main approaches to the professional training of agricultural specialists.

\section{Objectives of the study}

To analyze the pedagogical literature to identify the features of professional training of agricultural professionals.

\section{Methods of research}

Analysis of scientific sources and publications on the problem of research.

\section{Outline of the main research material}

At the present stage of socio-economic development of Ukraine, the requirements for the quality of agricultural education, which are determined by the goals and needs of this industry, are increasing. In view of this, the domestic agricultural industry needs an adequate level of staffing, which is an indispensable condition for its effective functioning and development, so graduates of agar higher education institutions must be highly qualified, competent, possess both theoretical knowledge and practical skills, professional and professional professional thinking. This increases the focus on the training of qualified agrarians.

An important component of the process of formation of the system of professional training of agricultural education specialists are the factors that control the development of agrarian industries, in particular:

* world trade and its requirements;

* EU agricultural policy;

* development of productive forces and technological progress;

* economic and social security of the farm;

* environmental protection. 
Now the domestic system of agrarian education provides replenishment of the agar industry of Ukraine by qualified specialists, whose preparation is carried out taking into account the prospects of development of modern agrarian production. realization of the set tasks before the national higher agrarian education in preparation of highly qualified specialists, as L. Romanenko rightly points out, is conditioned by the formation and stability of professional interests of students, the readiness of future specialists of agrarian higher educational institutions to work. This circumstance, emphasizes the researcher, is a prerequisite for the effectiveness and quality of training and is characterized by the employee's future activity [3, p.225].

The analysis of the scientific work of specialists in the problem of research gives us the opportunity to define our own concept of "readiness of future specialists of the agrarian industry for professional activity" as an awareness of the need for purposeful acquisition of theoretical knowledge, practical skills for the purpose of self-formation, awareness of personal and social profession sphere.

Modern agricultural education in Ukraine is undergoing reform. Most agricultural agrarian institutions are trying to move away from the post-Soviet traditions in agar training. There is an active introduction into the educational process of Ukrainian higher education elements of all types of education, not taking into account the peculiarities of the country, the mentality of the people, historical aspects of development, the possibility and acceptability of use in specific conditions. In such circumstances, educational activities in agricultural educational institutions are aimed at finding effective ways of improving the professional training of future professionals, ensuring the transformation of students' educational activities into professional ones with a corresponding change in needs, motives, goals. Agrarian education institutions are tasked with finding new forms, ways and means of organically combining the professional training of future specialists with the formation of deep scientific outlook, high professional culture, true intelligence, professionalism.

With the rise of social standards, the economic status of a rural citizen, the establishment of new economic relations in the countryside, the formation of a future specialist must go in the direction of greater universalization, the ability of the young person to determine the priority of activities, while using the acquired knowledge, acquired skills and skills to further and deepening depending on the direction of their professional activity. Nowadays, agro-industrial enterprises are installing high-tech equipment, introducing new technologies of animal nutrition, growing plant products and more. That is why a modern specialist should have the skills, techniques and methods of introduction of advanced technologies, ensure the optimal mode of operation of production equipment, constantly deepen knowledge of economics, law, management, marketing, be able to organize legal relations with farms; have organizational skills, engage in entrepreneurial activity, have communicative qualities in working with people and economic approaches to the organization of economic activity. The old scheme of in-depth division of labor in agriculture and, accordingly, the system of training of narrowly directed specialists has exhausted itself.

In the agricultural complex should work creative and initiative people who are able to grow agricultural products, process and sell it; they are mobile workers who are able to solve problems in a variety of form and content in ways that are knowledgeable and professionally competent. As a result - the inner will and unspoken personality, the ability to respond quickly to changes that are taking place in society, in agricultural science and practice, the ability to adapt to other (if necessary) professional activities. Therefore, the main task of agrarian education is to provide students with a proper set of knowledge, skills, acquaintance with the current state of agricultural production, achievements of agrarian sciences, sufficient amount of information to solve professional problems, as well as to educate future specialists in the agricultural sector to work independently and scientific literature, to monitor the development of new forms of education, to constantly update their knowledge with new progressive forms of training of agricultural specialists in new conditions of management. The training of future agricultural specialists has its own specificity, due to the fact that the majority of students of agrarian institutions are representatives of rural youth. Such students are positively distinguished by observation, attention to detail, closeness to nature.

Analyzing the psychological and pedagogical literature, we can say that the problem of forming a new generation of specialists in the agricultural sector is of great importance in the context of modern agrarian reform. «According to N. Matyash, agrarian reform, the creation of economic and legal bases for the equal existence of all forms of management requires the formation of a new type of specialist and requires changes in the content and quality of professional training of agricultural producers of all units» [5, p.112].

Taking into account the professional functions of agrarian specialists, we agree with N. Latushi's opinion on the prospects of professional training of future agrarians in higher agrarian education institutions of Ukraine, which «must focus their efforts on improving the system of professional training of specialists with higher agrarian and professional skills. in extraordinary circumstances; ability to introduce innovations and continuous self-improvement in the agricultural sector at the level of requirements of world standards; formation of intellectual potential necessary for a wide choice of specific directions of practical activity in modern conditions» [4, p. 119]. 
The peculiarity of the organization of educational process of agricultural educational institutions is their professional orientation and close connection with agricultural production and achievements of science and technology in this field. These are the peculiarities of a separate section of pedagogy - agrarian pedagogy.

The agrarian higher education of Ukraine, which is characterized by general shortcomings and problems of educational activity, also requires change. Acting Director of the State Institution "Scientific and Methodological Center of Information and Analytical Support for the Activities of Agroosvita" Higher Education Institute, T. Ishchenko emphasizes that today agricultural producers are dissatisfied with the quality of training. Higher and secondary education is often lacking in practical orientation, so graduates need more time to adapt [1, p.57].

An important and ambiguous problem of didactics of agricultural educational institutions of higher education is the problem of its content. With the development of society, there is a need to acquire more knowledge. Therefore, there is a contradiction at the intersection between the increase in knowledge of future professionals and the limited educational process in time, between the breadth of the training profile and the depth of specialization, and between the pace of advancement of scientific knowledge in the agricultural sector and conservatism of education. These contradictions are obvious and need immediate resolution.

The formation of a future specialist in the conditions of approval of new economic relations in the countryside must go in the direction of greater universalization, the young person's ability to prioritize their knowledge, skills and skills to further expand and deepen them, depending on the direction of their professional activity. Modern agricultural specialist must have the skills and methods of introduction of advanced technology, ensure the optimal mode of production equipment, constantly deepen knowledge of economics, law, management, marketing, be able to organize legal relations with farms; have organizational skills, engage in entrepreneurial activity, have communicative qualities in working with people and economic approaches to the organization of economic activity. Therefore, on the basis of the above, we can conclude that $« . .$. the practice of deep division of labor in agriculture and the corresponding system of training narrowly specialized workers has exhausted itself» [3; p.107]. This is where scientists see the cause of alienation of agrarian experts from the land, their loss of independence.

That is why the quality of higher education depends on some defining conditions, among which are the following: formation of a qualitative contingent of students and staff of universities, modern content of education, close connection of educational institutions with the labor market, internal and external higher education system, new model training of specialists, scientific certification of higher education institutions (HEI).

University education is one of the links in the future professional training of agrarian specialists and is based on the knowledge, skills and competences of all the studied subjects, and is united, systematized and transformed in the conditions of future professional activity. The curricula of agrarian educational institutions contain disciplines that are combined into the following cycles: fundamental, social, humanitarian, technical and special (including practical training). All these cycles and individual disciplines have direct or indirect access to the content of the professional activity of the future specialist in the production, determined by the qualification characteristic (professiogram) of the specialty.

Social and humanitarian disciplines shape the civic position of future specialists, legal and professional culture, promote the development of speech abilities and the acquisition of knowledge of customs, traditions, spiritual world of the people of Ukraine.

The special cycle of disciplines forms the knowledge, skills and competences that correspond to the specific professional functions of the future specialist of agricultural production and should be the final stage of the process of preparation of future specialists, in which the knowledge acquired during the entire period of study, is united in a single system.

It is important to emphasize that the connection between science and agrarian production is to a large extent manifested in the study of the cycle of technical disciplines, which provides the theoretical and practical basis for the professional development of a future specialist. In modern conditions, the content of vocational training is a collection of didactically selected, systematized on the basis of scientific provisions of the relevant sciences, concentrated around important problems of the specialty. Studying the course of technical disciplines should provide the future specialist with a share of vocational training with the acquisition of fundamental knowledge, skills and skills that will enable him to quickly adapt to the constantly changing agrarian industry and the labor market.

Today, the labor market is making new demands, so there is a need for mobile professionals who are able to learn and speak a foreign language; combine knowledge, skills and competencies across multiple specialties.

Modern conditions of agrarian production, advanced technologies, new machines and technical complexes require the formation of relevant competencies of future agrarian specialists and place high demands on their qualification.

However, the solution of these important tasks is hampered by a number of contradictions that have arisen between: 
* increasing the demands placed on society by the level of professional training of agricultural specialists, and the search for effective mechanisms for the development of the system of professional training of agricultural specialists;

* the need to synchronize the ways of development of professional training of agricultural specialists in Ukraine with the countries of the European Union and the state of socio-economic development of society ;.

* changes in land ownership, establishment of market relations between producers, the state and consumers and tasks of the system of professional training of agricultural specialists;

* the need to complement the traditional forms and methods of teaching modern technologies and the lack of organizational and methodological foundations for its introduction into the educational process of agricultural education institutions;

* international cooperation and integration of Ukraine into the European educational space and participation in international programs of agricultural education institutions;

* a significant amount of information on the professional training of agricultural professionals in the EU countries and the lack of use of this experience in Ukraine;

* modernization of the national system of professional training of agricultural specialists in the industry in Ukraine and quality assurance of agricultural products and environmental protection.

Factors that control the development of agriculture and its industries are influential levers to the process of forming the system of professional training of agricultural education specialists, in particular:

\# rules of world trade;

* development of EU agricultural policy;

* technological progress and development of agricultural sector productivity;

* socio-economic support of farms;

* state of the environment policy.

The analysis of the psychological and pedagogical literature gives us reason to claim that today the three paradigms of professional education are defined in theory and practice: cognitive, activity and personal.

Cognitive characterizes the level of students' acquisition of professional knowledge: understanding of the nature, content, goals and objectives of professional activity; possession of the system of knowledge necessary for the effective performance of professional tasks; knowledge of methods and methods of performing professional tasks.

Activity - the ability to use professionally important knowledge when solving professional tasks.

Personal implies the presence of professionally important personal qualities that influence the outcome of professional activity.

At present, meaningful transformations in the system of professional training of agricultural specialists are relevant, in particular it concerns the search for innovative forms, new methods, interactive learning technologies at all stages of the educational process in higher education. It becomes necessary to switch to training systems focused on the formation of both the personal qualities of a specialist and the competences in future professional activity. However, the cardinal changes occurring in the domestic higher agricultural education, the new conditions of its functioning require a significant adjustment of the educational process.

Also, the issue of electronic textbooks and textbooks in Ukrainian for students, taking into account modern educational technologies, will contribute to the positive solution of these problems.

Pedagogical technologies should ensure that the constantly changing conditions of agricultural production are taken into account. The future specialist should easily adapt to new production conditions.

Effective professional training of future specialists in educational agrarian institutions can be realized under the conditions of realization of pedagogical system of purposeful formation of educational and cognitive activity of students, which would perform the following functions:

a) created psychological and pedagogical conditions for increasing the effectiveness of specialist training for agricultural production;

b) take into account the stage of formation of students' educational and cognitive activity from reproductive to productive, creative levels;

c) was based on such basic elements as forms, methods of teaching, pedagogical activity of the teacher, cognitive abilities of the student, interpersonal relationships in the student group;

d) was based on general and specific principles of activation of training;

e) took into account the main didactic ways of forming activity as a psychological formation of personality. 
It should be noted that the professional development of the future specialist is based on appropriate motives and needs, which play an important role in the professional preparation of agricultural students.

According to the study of motives and needs of students' personality with the use of research methods, we have identified three stages of professional preparation of students in higher education.

And the stage is the inclusion of the student in the educational process and his joining a new team. Despite the fact that the freshman is already a student, he actually becomes him when he can overcome the difficulties of adaptation, to believe in himself. It is during this transition period that the beginner learns different types of educational activities: note-taking, work with primary sources, preparation for practical and laboratory classes, public student life. Make new acquaintances, the student participates in the public life of the educational institution, learns to properly allocate his time.

Further education contributes to the gradual improvement of objective and subjective indicators of student activity, which is characteristic of the second stage. The revitalization of subjective relations facilitates the acquisition of new information in the process of acquiring theoretical knowledge with involvement in the elements of industrial activity. It is during this period that students begin to study special disciplines that arouse interest in the profession and stimulate the formation of professional skills.

The analysis of the scientific and pedagogical literature allows us to determine the organizational and methodological means of ensuring the educational process, which are:

* regulations in the field of higher agricultural education (laws, regulations, orders, qualifications);

\# state industry standards, standards for the organization of educational activities, etc.);

\# scientific (concepts, principles, innovative approaches);

* educational (curricula, discipline programs, textbooks, manuals, electronic educational resources, etc.);

* methodical (innovative methods, teaching aids, instructional, methodical materials for independent, laboratory, practical work, etc.);

* materials that describe the content, determine the structure, predict the outcome, regulate the sequence and flow of theoretical, practical training and industrial practices.

The tasks and principles of organizational and methodological work are implemented in the following areas: diagnostic and prognostic, educational and methodical, organizational and coordination.

\section{Summary}

Thus, the need to increase the efficiency of the educational process in the agar institutions of Ukraine, taking into account the social, socio-economic and cultural changes taking place in the country, changing the priorities of science and education as the main conditions for the revival of Ukrainian statehood becomes a nationwide problem. To this end, training should be provided for such a specialist who is capable of thinking independently, creatively, possessing profound professional knowledge, skills, skills, techniques and methods of introduction of advanced technologies, possessing organizational skills and personal skills, important for work in the field of production and skills. be a professional mobile specialist. This approach will allow to fully realize the intellectual potential of students, to meet the requirements of the individual and the society for education, to create conditions for effective restructuring of the system of continuous education in Ukraine, while improving the quality of professional training of future specialists in agricultural education. We see further research prospects in the analysis of didactic aspects of professional training of agricultural students.

\section{References}

[1] Ishchenko, T.D., Nahirnyy, Yu.P., \& Bendera, I.M. (1997). Pryntsypy formuvannya osvitn'o-kvalifiatsiynykh rivniv i zmistu fakhovoyi pidhotovky inzhenerno-tekhnichnykh kadriv [Principles of Formation of Educational Qualifiation Levels and Content of Professional Training of Engineering and Technical Personnel]. Proceedings of the International scientifi-methodical condference «Graduate system of higher agricultural education: concept, actual problems and implementation mechanization. Kyiv: APS of Ukraine. [in Ukrainian].

[2] Kobernyk, A.N. (1984). Sovershenstvovanye form $y$ metodov podhotovky starsheklassnykov k trudu v sel'skokhozyaystvennom proyzvodstve [Improving the forms and methods of preparing high school students for work in agricultural production]. Extended Abstract of Canidate'i Thesis. KSU named afeter T.G.Shevchenko, Kyiv. [in Ukrainian].

[3] Zaskaleta S., Sisoyeva S. (2.13). Trends of professional training of agricultural specialists in the countries of the European Union: monograph [Training of agricultural specialists in the countries of the European Union].Nikolaev: Ilion. [in Ukrainian]. 
[4] Latusha N.V. (2015) Features of professional training of future agronomists in agricultural universities [Professional training of agricultural specialists]. . Drogobych. Young scientist. № 5(20). Pp. 116-119.

[5] Matyash, N.Yu. (1994). Formuvannya u starshoklasnykiv profesiynoyi spryamovanosti na sil's'kohospodars'ki spetsial'nosti u vzayemodiyi shkoly ta vuzu [Formation of vocational training for senior pupils in agricultural specialties in interaction between school and university]. Unpublished Candidate`s Dissertation. Institute of Pedagogics of the Academy of Pedagogical Sciences of Ukraine, Kyiv. [in Ukrainian].

[6] Presidential Decree «Pro natsionalnu stratehiyu rozvytku osvity v Ukrayini na period do 2021 roku [About the National Strategy for the Development of Education in Ukraine until 2021. URL: https://zakon.rada.gov.ua/laws/show/344/2013 [last accessed: 16.03.2019]. 